\title{
Endobronchial electrocautery and argon plasma coagulation: A practical approach
}

\author{
Alain Tremblay MDCM FRCPC FCCP ${ }^{1}$, Charles-Hugo Marquette MD²
}

A Tremblay, C-H Marquette. Endobronchial electrocautery and argon plasma coagulation: A practical approach. Can Respir J 2004;11(4):305-310.

The present review covers the technical and practical aspects of endobronchial electrocautery, including argon plasma coagulation, which have great potential for widespread use by pulmonologists around the world. The various electrocautery modes, power settings and electrode probes are described in detail, and the authors' clinical and technical approach is demonstrated with a narrative description and brief case presentations. Malignant airway obstruction, hemoptysis, web-like stenosis, stent related granulation tissue and early lung carcinomas are the most common indications for treatment. Advantages of electrocautery, such as low cost, rapid effect, safety and ease of use, are contrasted to other endobronchial therapeutic modalities. Published experience with electrocautery is reviewed.

Key Words: Argon plasma coagulation; Bronchoscopy; Electrocautery; Laser; Lung cancer; Tracheal stenosis

C ndoscopic treatment of pulmonary malignancies has $\mathbf{E}_{\text {progressed dramatically in the past } 20 \text { years, resulting }}$ in the availability of a range of therapeutic tools for the interventional bronchoscopist. The present report aims to review the technical and practical aspects of endobronchial electrocautery (EE) and argon plasma coagulation (APC), which have great potential for widespread use by pulmonologists around the world. The various EE modes, power settings and electrode probes are described. Our approach to the palliative and curative aspects of endoscopic treatment of airway malignancies is detailed, and published results are reviewed.

\section{THEORETICAL BACKGROUND AND TISSUE EFFECTS}

The therapeutic properties of EE are mediated via the thermal effects of high-frequency electrical currents flowing through tissues (1). Techniques used for bronchoscopy are monopolar because the current passes from the electrode and completes the electrical circuit through an electrical plate on the patient's skin. Various coagulation or cutting effects can be achieved by changing current waveform properties (Figure 1). Each of these waveforms corresponds to a given EE mode on commercially available electrical generators.

\section{Approche pratique à l'électrocautérisation et à la coagulation endobronchique à l'argon}

Le présent article de synthèse aborde les aspects techniques et pratiques de l'électrocautérisation endobronchique, y compris par coagulation plasmatique à l'argon, technique la plus susceptible d'être largement utilisée par les pneumologues dans le monde. Les multiples modalités d'électrocautérisation. Les paramètres de contrôle et les sondes sont décrits en détail et l'approche clinique et technique des auteurs est démontrée par le biais d'une description narrative et de brèves présentations de cas. L'obstruction des voies respiratoires par des néoplasies, l'hémoptysie, la sténose en toile des tissus de granulation associés aux endoprothèses et les premiers stades du cancer du poumon sont les plus fréquentes indications du traitement. Les avantages de l'électrocautère, tout comme son faible coût, son effet rapide, son utilisation sécuritaire et facile, contrastent avec les autres modalités thérapeutiques endobronchiques. L'article passe aussi en revue les expériences publiées sur l'électrocautère.

\section{EE modes}

Cutting effects are obtained with voltages high enough to create electric arcs between the electrode and tissues (greater than $200 \mathrm{~V}$ ), resulting in immediate vaporization. The depth of coagulation surrounding the cut can be increased by raising the peak voltage and introducing voltage modulation (blend modes).

Coagulation can be achieved by heating tissues near $70^{\circ} \mathrm{C}$ while avoiding tissue evaporation (greater than $100^{\circ} \mathrm{C}$ ) and carbonization (greater than $200^{\circ} \mathrm{C}$ ).

In soft coagulation, unmodulated voltages of less than $200 \mathrm{~V}$ are applied with the electrode in direct contact with tissue, avoiding electrical arc formation and preventing carbonization and charring. This setting cannot be replicated by using a generator in a cut mode at a low power setting, as voltages of less than $200 \mathrm{~V}$ cannot be guaranteed. Only generators with 'voltage control' capacity can ensure voltages less than $200 \mathrm{~V}$, and therefore, the absence of electrical arc formation.

Forced coagulation or desiccation uses modulated, higher voltage (greater than $500 \mathrm{~V}$ ) currents and creates electrical arcs to obtain deeper coagulation, but risks tissue carbonization.

Spray coagulation or fulguration is a noncontact mode in which long electrical arcs are created with a high-voltage (greater than $2000 \mathrm{~V}$ ), strongly-modulated current, leading to surface coagulation. If direct contact occurs between the probe and tissue, a cutting effect on the tissues may be seen.

${ }^{1}$ Division of Respiratory Medicine, University of Calgary, Calgary, Alberta; ${ }^{2}$ Clinique des Maladies Respiratoires, Hôpital A Calmette, CHRU de Lille, France

Correspondence: Dr Alain Tremblay, Health Sciences Centre, 3330 Hospital Drive North West, Calgary, Alberta T2N 4N1.

Telephone 403-210-3866, fax 403-283-6151, e-mail alain.tremblay@ucalgary.ca 


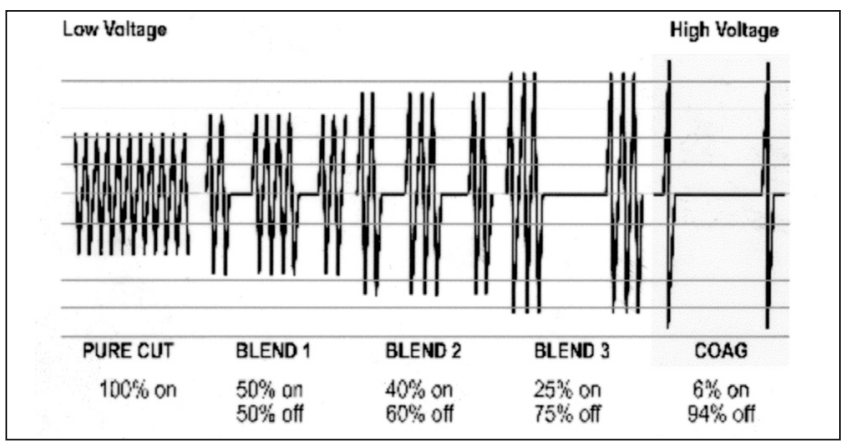

Figure 1) Voltage waveforms for cut, blend and coagulation modes. Note that the soft coagulation mode has the same configuration as the cut mode, but at a lower voltage. COAG Coagulation

APC is a noncontact mode electrocautery similar to spray coagulation, in which the electrical arc created between electrode and tissues is conducted via a cloud of ionized argon gas continuously flowing from the tip of the probe. This results in rapid superficial coagulation of tissues. This mode is essentially a variant of EE, but is often referred to in the literature as a separate endobronchial modality. Advantages over spray coagulation may include a more controlled superficial coagulation (approximately $3 \mathrm{~mm}$ ); decreased carbonization, smoke and unpleasant smell; and no risk of cutting effect if the probe contacts the tissue (the actual tip of the electrode is inside the distal end of the probe and cannot physically enter in direct contact with the tissues). On the other hand, additional probes and generators are required, increasing the cost.

\section{EE power settings}

The power setting must also be set on most generators. The exact numbers of watts (W) or generic one to 10 scales are used in different models. Increasing power leads to concentration of the electrical energy in tissues closer to the tip of the electrode, resulting in rapid but shallower effects. This counterintuitive effect is due to the more rapid coagulation of tissues close to the probe, leading to increased tissue impedance. Similarly, a small electrode will concentrate the energy over a smaller surface so that power is generally reduced when using such small probes to obtain sufficient depth of coagulation. Other variables impacting tissue effects are duration, type of tissue and eschar formation.

\section{Pathological effects}

Acute pathological effects of $\mathrm{EE}$ in the coagulation mode include mucosal ulceration and inflammation to the depth of the perichondral spaces $(2,3)$. These changes evolve into fibrosis and loss of chondrocyte viability, frequently resulting in extrinsic and/or intrinsic stenoses if circumferential coagulation of the airway is performed. The severity of damage does not appear to be dependant on the power (W) setting (2), but does increase with duration of the application (3). APC has a more superficial effect and is less likely to injure cartilage, although no detailed pathological study of its endobronchial effects has been published.

\section{PATIENT SELECTION,}

\section{INDICATIONS AND CONTRAINDICATIONS}

Indications for EE mirror those for neodymium:yttriumaluminum-garnet (Nd:YAG) laser photocoagulation, the most important being the rapid palliative treatment of malignant
TABLE 1

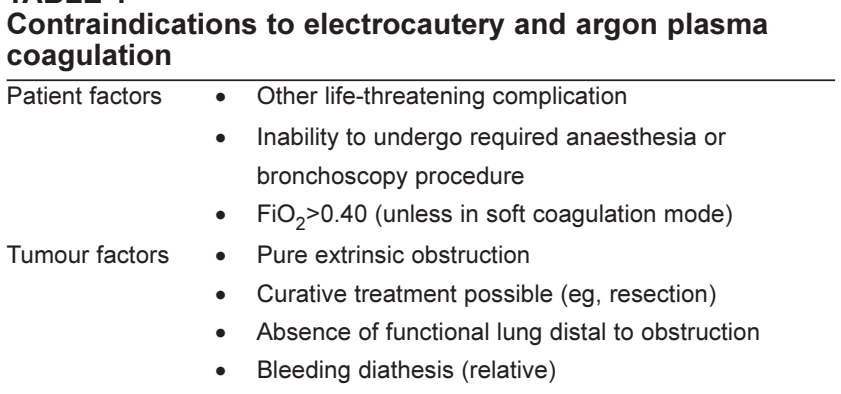

$\mathrm{FiO}_{2}$ Fraction of inspired oxygen

endobronchial obstruction of large airways (4-17). Although it is generally agreed that complete airway obstruction is a contraindication to laser therapy, it is possible in a contact EE mode to treat lesions with $100 \%$ obstruction of the airway lumen with little risk of perforation.

Selected patient should be symptomatic (dyspneic) from the airway lesion. Functional status should allow the possibility for a reasonable life expectancy following the procedure. Treatment of lesions obstructing lobar (or smaller) bronchi, predictably result in more modest improvements in symptoms compared with tracheal or mainstem lesions.

Hemoptysis secondary to endobronchial tumours, including more peripheral endobronchial lesions, can be successfully palliated with EE as well. We find the APC mode best suited for the rapid superficial coagulation of these lesions, although other EE coagulation modes can be used $(14,17,18)$. In patients unable to receive additional radiation therapy, EE is the preferred therapeutic modality for malignant hemoptysis.

Less common indications for EE include curative treatment of lung carcinoma in situ (CIS) (19) or localized carcinoid tumours (20), removal of granulation tissue $(15,21)$, radial ablation of simple benign web-like stenoses (in cut mode) (22) and treatment of other benign lesions (23).

Contraindications are listed in Table 1 . The presence of a pacemaker, while not an absolute contraindication to $\mathrm{EE}$, does warrant additional precautions because deprogramming of devices has been reported following electrocautery application. As such, a technician with the instruments required to reprogram the unit should be present during the procedure if $\mathrm{EE}$ is to be used.

\section{Bronchoscopes and anesthesia}

\section{DESCRIPTION OF TECHNIQUE}

EE can be performed via rigid or flexible bronchoscopy, the choice of which depends on the general medical and respiratory condition of the patient, the level of cooperation of the patient, the urgency and anticipated length of the procedure, the estimated risk of complications, such as bleeding and the expertise of the bronchoscopy team. We suggest that patients in respiratory distress should always be approached with the rigid bronchoscope under general anesthesia.

Insulated flexible bronchoscopes should be used with all modes of electrocautery. The electrode tip must not come into contact with the rigid scope or its instruments, avoiding the formation of an electrical circuit with the equipment and operator in its path.

Anesthesia for interventional procedures is beyond the scope of the present report and is reviewed elsewhere (24). We perform the majority of our procedures via rigid bronchoscopy 
under total intravenous anesthesia consisting of propofol, a short acting opiate and neuromuscular blocker. EE has also been well described with flexible bronchoscopy and conscious sedation, but should be limited to the treatment of small nonobstructive lesions in stable patients (15).

The fraction of inspired oxygen $\left(\mathrm{FiO}_{2}\right)$ must be reduced below 0.40 in all modes leading to electrical arc formation in order to avoid intrabronchial fires, although an $\mathrm{FiO}_{2}$ as high as 1.00 can be used safely in a soft coagulation mode given the lack of electrical arc formation with this modality.

\section{Electrosurgical generators and probes}

Several electrocautery units are commercially available, all with different settings and operating modes, making careful review of the respective technical manuals and specific training sessions on a particular unit is critical before their use. The safest configuration is a soft coagulation contact mode, which avoids electrical arc formation (and, therefore, risk of ignition), combined with an autostop function which automatically ends current flow when tissue resistance increases to a preset level (at the point of vapour formation), avoiding charring and burning of the tissues, which may adhere to the probe tip and impair further treatment. Without this function, coagulation must be halted by the operator as soon as vapour is seen and the probe cleaned more often.

Another helpful feature is automatic voltage control, which automatically adjusts delivered voltage according to changes in tissue impedance and effective surface area, resulting in a more constant effect on the tissues.

Various electrodes are available, examples of which are shown in Figure 2. Simple blunt monopolar probes are used for soft, forced or spray coagulation, and are available in flexible or semirigid models for flexible and rigid bronchoscopic use. Loop snares and hot biopsy forceps can also be useful and their use is described below. Specific probes (flexible or rigid) are required for APC. All of the probes mentioned above are reusable, although some APC probes are now available in a disposable form. Finally, a small EE knife is available for use in cutting modes.

A grounding pad must be placed on the patient, usually on the arm or hip nearest the planned treatment site, taking care to ensure that a large area of skin is in contact with the pad to avoid burns as the current exits the body. Most units have automatic alarms and stop functions if any current leak is detected or if the grounding pad is improperly positioned.

\section{Malignant lesions}

For the treatment of obstructing lesions (Figure 3A,B), the electrocautery probe is set in a soft coagulation mode, between $40 \mathrm{~W}$ to $60 \mathrm{~W}$, with autostop, which is used to coagulate lesions from the base up and from proximal to distal. The tip of the probe is inserted into the mass and current applied with a foot pedal until autostop is activated or when whitening of the area occurs, if the generator does not have this autostop feature (Figure 3C).

Once the lesion is well-coagulated, tissue can be removed with the tip of the rigid bronchoscope or with forceps while ensuring the dissection plane remains parallel to the airway being treated (Figure 3D). Extreme care must be taken in cases involving concurrent extrinsic obstruction so as not to damage

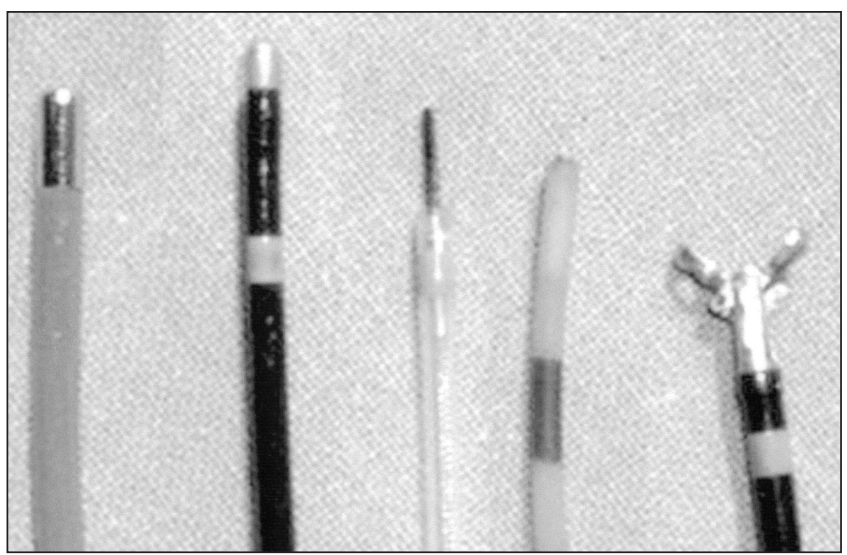

Figure 2) Electrocautery probes for use in bronchoscopy (from left to right): semi-rigid blunt probe, flexible blunt probe, electrocautery knife, flexible argon plasma coagulation probe and hot biopsy forceps

the airway wall and cartilage. As well, detailed knowledge of the anatomy of vascular structures surrounding the airway is crucial to avoid potentially catastrophic complications.

Repeat cleaning of the probe tip during the procedure is required for optimum performance. Repeated cycles of coagulation followed by resection are applied until acceptable results are achieved. Limitations of the flexible approach become evident if a large tumour bulk requires resection.

Following EE treatment, consideration should be given to additional treatments, such as stent placement and/or radiotherapy, if there is an extrinsic component to the obstruction or to prevent re-obstruction (Figure 3E). Immediate re-expansion of the atelectatic lung is usually seen on postoperative chest radiograph (Figure $3 \mathrm{~F}$ ).

An alternate approach using a wire snare in a soft coagulation mode can be applied for the occasional polypoid type lesion (25). The wire is wrapped around the base of the lesion and the loop is gently tightened while current is applied. The bronchoscopist must be ready and able to then retrieve the lesion as one would a foreign body.

Bleeding lesions can be quickly coagulated in a contact coagulation mode, a spray coagulation mode, or preferably, with APC. In APC, the generator is set in a "Spray Coag" mode with a power setting of $40 \mathrm{~W}$ to $60 \mathrm{~W}$. The flow of argon gas is automatically adjusted according to the specific APC probe used.

Curative attempts for CIS can be accomplished with the tip of the probe in a soft coagulation mode, taking care to coagulate the entire tumour area.

\section{Benign lesions}

Fibrous web stenoses can be treated with the knife electrode in a cutting mode (22). Two to four radial incisions are followed by dilation with a balloon or rigid bronchoscope. (Figure 4A-D) Extreme care is warranted when using this instrument, as the knife can easily cut through tracheal cartilage (Dr Marquette, personal experience in an animal model). Small granulomas can be easily treated with EE or APC. There is little use for EE in the treatment of complex benign stenoses.

\section{Diagnostic use}

Special biopsy forceps are also available and can be used to biopsy hemorrhagic lesions while simultaneously applying a coagulation 


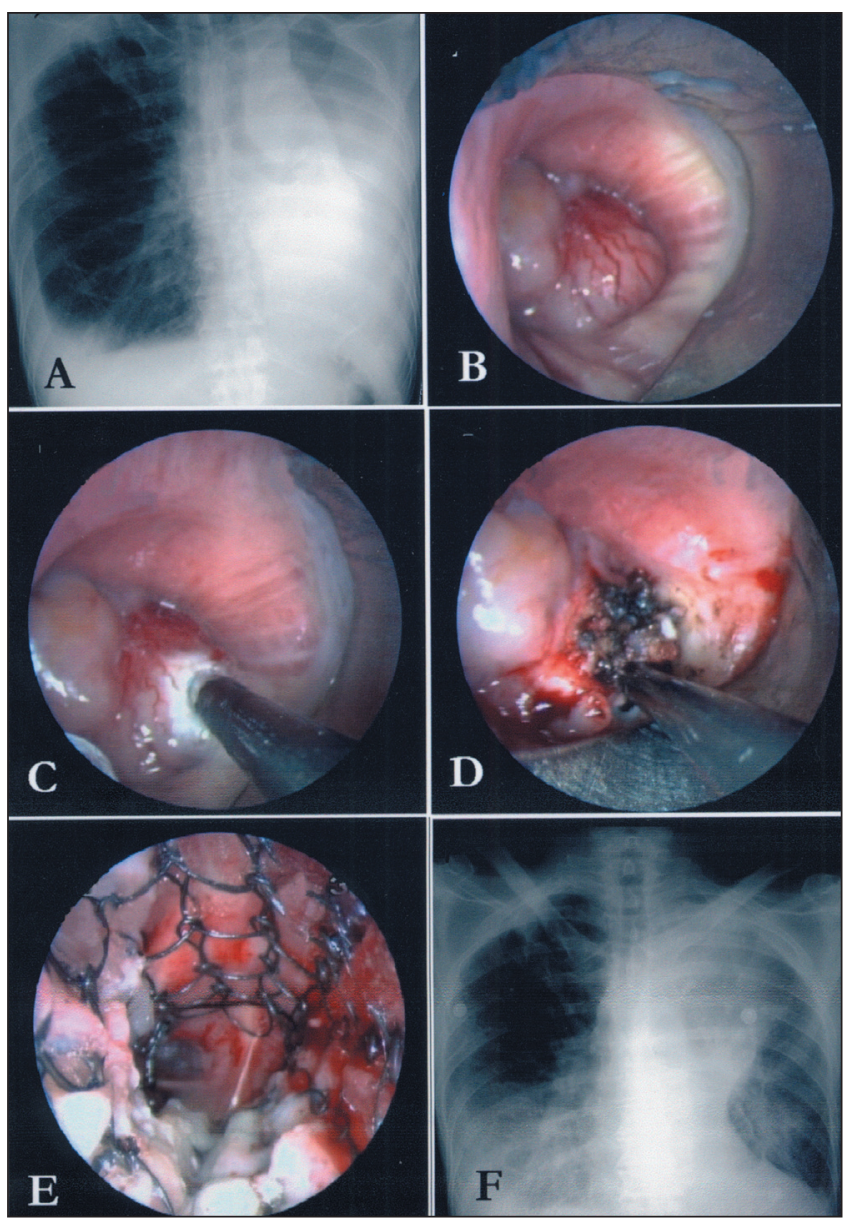

Figure 3) Treatment of a 58-year-old man with a recent diagnosis of stage IIIb lung adenocarcinoma and severe hypoxemia resulting from endobronchial obstruction at the level of the distal left mainstem bronchus. A Chest x-ray demonstrating left lung atelectasis; B Endobronchial lesion at the distal end of the left main bronchus arising from the left upper lobe and completely obstructing the left lower lobe; C Semi-rigid electrocautery probe blanching the lesion in coagulation mode; D Further electrocoagulation of the lesion; E Placement of covered, self-expandable stent into the left mainstem and left lower lobe to treat the extrinsic component of the obstruction and prevent tumour regrowth (only the uncovered distal end of stent is seen in image). The three basilar segments are seen to be patent, but the left upper lobe and superior segment of the lower lobe could not be re-opened. This type of stent was chosen in view of the length, size and irregular shape of the airway involved; F Chest $x$-ray following the procedure, demonstrating re-expansion of the left lower lobe. Oxygen requirement was reduced to $3 \mathrm{~L} / \mathrm{min}$ via nasal canula from high flow oxygen (15 L/min) by mask preoperatively

current through the forceps, although we are not aware of published data documenting reduced bleeding rates or lack of impact on quality of the pathological specimen. An alternative is the use of regular biopsy forceps, with a blunt electrocoagulation probe or APC on stand-by should significant bleeding occur.

\section{Results with EE}

\section{LITERATURE REVIEW}

Results from several small studies (Table 2) attest to the feasibility and excellent early palliative results of EE in patients with airway obstruction (4-18). Although no randomized studies exist, success rates appear similar to those in studies using $\mathrm{Nd}$ :YAG laser photocoagulation (16). Potential practical advantages of EE

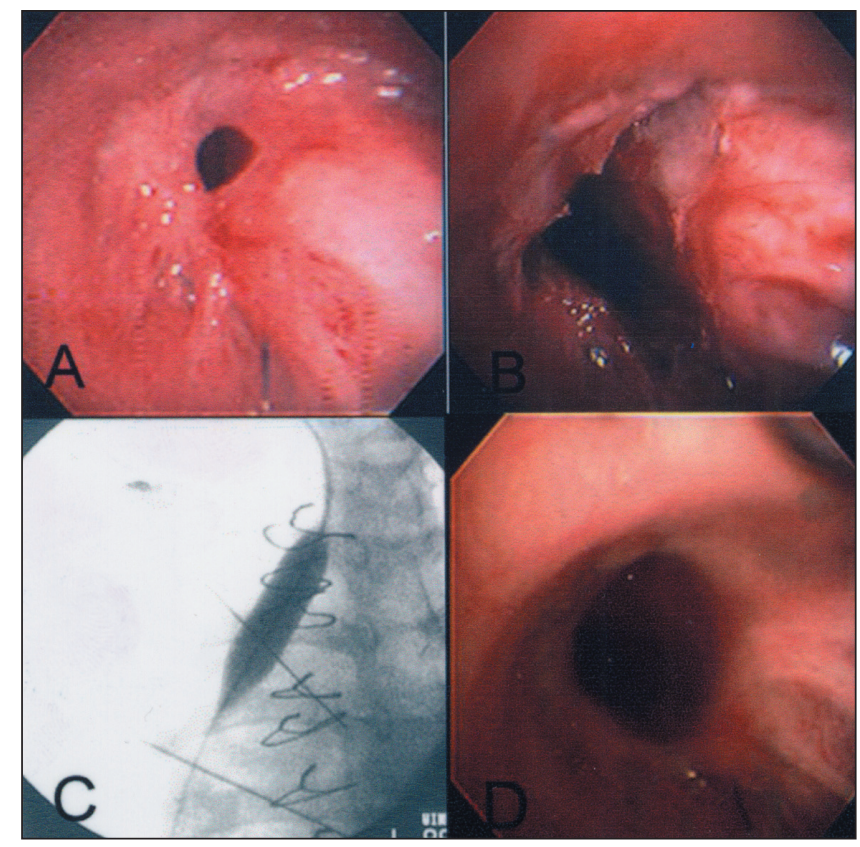

Figure 4) Treatment of a 43-year-old man with chronic thromboembolic pulmonary hypertension who underwent bilateral lung transplantation and developed a simple web-like stenosis at the right bronchial anastomosis; A Right mainstem bronchus at the level of lung transplant anastomosis demonstrating a web-like stenosis; B Stenosis following radial electrocautery ablation with electrocautery knife in cut mode; C Fluoroscopic view of balloon dilation; D Appearance of anastomosis eight weeks postprocedure. Forced expiratory volume in the first second and forced vital capacity increased postprocedure from 58\% to $83 \%$ and $60 \%$ to $79 \%$ of predicted normal values, respectively. (Photo courtesy of Dr AC Mehta)

over the use of the laser include lower costs of equipment and operation (16), absence of personnel safety issues present during laser operation, lower risk of airway perforation and an easier learning curve. The rapid results obtained with EE are the main advantage over both cryotherapy and brachytherapy; the latter is also associated with significant costs. The delayed effects, costs and phototoxicity associated with currently available photosensitizers make photodynamic therapy (PDT) a poor alternative to EE for palliation of malignant airway obstruction.

As for the curative treatment of CIS, one pilot study reported that 10 of 13 patients with lesions of less than $1 \mathrm{~cm}^{2}$ experienced complete pathological responses when treated with EE (19). Nine of 10 typical carcinoid lesions without peribronchial tumour extension were also successfully treated by the same group (20). Again, no comparative data exists between any of the previously mentioned modalities (Nd:YAG, PDT, cryotherapy) and EE in this patient population. Further studies in the treatment of early lung cancer will be crucial if early detection methods for lung cancer become part of clinical practice in the future. Patient selection for endobronchial curative treatment is critical, and data is emerging regarding the role of high resolution computed tomography, autofluorescence bronchoscopy and endobronchial ultrasound in pretreatment evaluation.

\section{Results with APC}

Published clinical reports describing APC in a variety of clinical situations are increasing $(14,17,18,21)$. In the largest study (14), 482 applications of APC were performed in 372 patients. 
TABLE 2

Electrocautery in malignant endobronchial obstruction

\begin{tabular}{|c|c|c|c|c|c|}
\hline Authors & $\mathbf{n}$ & Method & Results & Survival & Complications \\
\hline Hooper and Jackson (4) & 4 & FOB, EE snare, probe & All successful & $\mathrm{n} / \mathrm{a}$ & 1 tracheal fire \\
\hline Frizelly (5) & 17 & FOB EE, GA/LA & 16 with good results & $1-9$ months & 1 hemorrhage \\
\hline Gerasin and Shafirovsky (6) & 6 & $\begin{array}{l}\text { Rigid, EE snare and } \\
\text { mechanical ebridement }\end{array}$ & $\begin{array}{l}\text { Complete patency in } 3 \text {, partial in } \\
4 \text { patients }\end{array}$ & $\mathrm{n} / \mathrm{a}$ & - \\
\hline Hooper and Jackson (7) & 8 & FOB, EE snares, probe & $\mathrm{n} / \mathrm{a}$ & $\mathrm{n} / \mathrm{a}$ & - \\
\hline Ledingham and Goldstraw (8) & 15 & $\begin{array}{l}\text { Rigid, diathermy EE loop } \\
\text { and radioactive gold grains }\end{array}$ & $\begin{array}{l}\text { Symptom improvement in } \\
11 \text { patients alive at } 1 \text { month }\end{array}$ & median 2.5 months & $\begin{array}{l}1 \text { pa - bronchus fistula } \\
1 \text { tracheoesophageal fistula } \\
1 \text { pneumonia }\end{array}$ \\
\hline Petrou et al (9) & 24 & Rigid, diathermy EE loop & $\begin{array}{l}23 \text { patients with symptom } \\
\text { improvement }\end{array}$ & $\mathrm{n} / \mathrm{a}$ & $\begin{array}{l}1 \text { postoperative clot obstructing } \\
\text { left main stem } \\
1 \text { death due to respiratory failure } \\
\text { at } 24 \mathrm{~h}\end{array}$ \\
\hline Pederson et al (10) & 10 & Rigid EE loop & $\begin{array}{l}\text { Good palliative results in } 9 / 10 \text { patients, } \\
4 \text { adenocystic carcinoma, } \\
\text { one death at day } 1 \text { postoperation }\end{array}$ & 1 day-29 years & $\begin{array}{l}\text { Described as "minor" and at a } \\
\text { "very low rate" }\end{array}$ \\
\hline Sutedja et al (11) & 17 & Flex, blunt EE probe & $\begin{array}{l}11 \text { patients lumen }>75 \%, 8 \text { with } \\
\text { symptom improvement }\end{array}$ & $\mathrm{n} / \mathrm{a}$ & $\begin{array}{l}\text { Contralateral pneumonia } \\
\text { secondary to aspirated pus } \\
1 \text { bleeding }\end{array}$ \\
\hline Homasson et al (12) & 28 & FOB/RB EE & $\begin{array}{l}\text { Improvement in dyspnea in } 53 \% \text {, } \\
<50 \% \text { deobstruction in } 4 \text { patients }\end{array}$ & $\mathrm{n} / \mathrm{a}$ & 2 hemoptysis ( 1 fatal) \\
\hline Sutedja et al (13) & 51 & FOB EE, GA/LA & Improvement in $70 \%$ & & 1 bleeding \\
\hline Reichle et al (14) & 186 & $\mathrm{APC}$, mostly via rigid probe & Objective achieved $67 \%$ & $\mathrm{n} / \mathrm{a}$ & $\begin{array}{l}5 \text { tracheobronchial perforations, } \\
5 \text { delayed airway wall necrosis } \\
\text { (all associated with radiation } \\
\text { therapy) } \\
2 \text { damaged bronchoscope tips } \\
1 \text { myocardial infarction } \\
1 \text { hypovolemia } \\
3 \text { strokes }\end{array}$ \\
\hline Coulter and Mehta (15) & 13 & Flex, blunt, snares EE & $\begin{array}{l}89 \% \text { success including } 25 \text { benign } \\
\text { lesions }\end{array}$ & $\mathrm{n} / \mathrm{a}$ & 4 episodes of bleeding \\
\hline van Boxem et al (16) & 17 & Rigid EE loop or flexible probe & Symptom improvement in $13(76 \%)$ & mean $11.5 \pm 3.5$ months & 1 hemoptysis/respiratory failure \\
\hline Morice et al (17) & 38 & APC via flexible probe & Improved symptoms in all but one & $\mathrm{n} / \mathrm{a}$ & $\mathrm{n} / \mathrm{a}$ \\
\hline \multicolumn{6}{|c|}{ Electrocautery in bleeding endobronchial lesions* } \\
\hline Homasson et al (12) & 12 & FOB/RB EE & Hemostasis in 11 & $\mathrm{n} / \mathrm{a}$ & $\mathrm{n} / \mathrm{a}$ \\
\hline Reichle et al (14) & 115 & APC, via rigid or flexible probe & Success in 114 & $\mathrm{n} / \mathrm{a}$ & See above \\
\hline Morice et al (17) & 55 & APC via flexible probe & Hemostasis in all patients & $\begin{array}{l}\text { No recurrences } \\
\text { during follow-up } \\
\text { at } 97 \pm 92 \text { days }\end{array}$ & $\mathrm{n} / \mathrm{a}$ \\
\hline
\end{tabular}

*Several of the listed studies included patients with benign disease, which were excluded from these results. APC Argon plasma coagulation; EE Endobronchial electrocautery; FOB Fiberoptic bronchoscopy; GA General anesthesia; LA Local anesthesia; n/a Not available; pa Pulmonary artery; RB Rigid bronchoscopy

Successful outcomes were described in 124 of 186 patients with malignant airway stenosis, 118 of 119 patients with bleeding lesions and all 36 patients with stent-related infiltration. Attempts to close bronchopleural fistulas in six patients failed in all cases, which is in keeping with our personal experience. Direct complications of APC included five cases of bronchial perforation and two endobronchial fires. Two deaths occurred and three patients suffered reversible neurological events. At least five more patients developed delayed airway wall necrosis when APC was combined with radiation therapy. The overall complication rate was $3.7 \%$. The excellent results for patients with bleeding lesions have been corroborated in another study (17), and in our opinion, is the best indication for APC.

\section{COMPLICATIONS}

Complications directly related to $\mathrm{EE}$ and $\mathrm{APC}$ are rare. In practice, this is limited to endobronchial ignition in modes generating electrical arcs (ie, all modes except "Soft Coag") if the $\mathrm{FiO}_{2}$ is maintained above 0.40 , or if it is used too close to flammable material, and to secondary bronchial stenosis secondary to cartilage damage if circumferential EE of the airway is applied. Airway wall perforation has also been reported, usually following combined endoscopic and radiation treatments. Cerebral gas embolism is another potential complication previously described with laser bronchoscopy, which can also occur with EE and APC. We believe that EE in a contact mode and soft coagulation is particularly safe compared with 
other endobronchial therapies, as is APC, given its superficial effect. Other reported procedure related complications for EE and APC also include bleeding, pneumonia, myocardial infarction, stroke and hypoxemia. While the small size of the reported studies make it difficult to estimate the exact frequency of major complications, these likely occur in less than $5 \%$ of patients when good selection of cases and attention to detail during the procedures is maintained.

Contrast between EE, APC and other endobronchial modalities It is our opinion that EE and APC are safe, effective and versatile tools for a variety of endobronchial treatment indications. Given the paucity of comparative studies among various endobronchial modalities, choice of one tool over another is based on knowledge of their effect, cost and personal experience. As noted, $\mathrm{EE}$ and APC seem as effective as laser for endobronchial lesions, but it is less expensive, easier to operate, and in our opinion, safer for both the patient and the treatment team.

While their costs are similar, the advantages of EE and APC over cryotherapy include immediate results in airway debulking (essential for critical obstructions) and ability to treat hemorrhagic and fibrous lesions. Cryotherapy has the advantage of safety, having no effect on airway cartilage.

We find brachytherapy useful for treatment of diffuse distal airway disease where EE and APC, and stent insertion are difficult, or as an adjuvant treatment following bronchoscopic therapy to delay recurrence of malignant obstruction. Its

\section{REFERENCES}

1. Homasson JP. Endobronchial electrocautery. Sem Resp Crit Care Med 1997;18:535-43.

2. Verkindre C, Brichet A, Maurage CA, Ramon P, Homasson JP, Marquette $\mathrm{CH}$. Morphological changes induced by extensive endobronchial electrocautery. Eur Respir J 1999;14:796-9.

3. van Boxem TJ, Westerga J, Venmans BJ, Postmus PE, Suteja TG. Tissue effects of bronchoscopic electrocautery: Bronchoscopic appearance and histologic changes of bronchial wall after electrocautery. Chest 2000;117:887-91.

4. Hooper RG, Jackson FN. Endobronchial electrocautery. Chest 1985;87:712-4.

5. Frizelli R. Le traitment par électrocoagulation en pathologie maligne trachéo-bronchique. Rev Mal Resp 1986;42:235-7.

6. Gerasin VA, Shafirovsky BB. Endobronchial electrosurgery. Chest 1988;93:270-4.

7. Hooper RG, Jackson FN. Endobronchial electrocautery. Chest 1988;94:595-8

8. Ledingham SJM, Goldstraw P. Diathermy resection and radioactive gold grains for palliation of obstruction due to recurrence of bronchial carcinoma after external irradiation. Thorax 1989;44:48-51.

9. Petrou M, Kaplan D, Goldstraw P. Bronchoscopic diathermy resection and stent insertion: A cost effective treatment for tracheobronchial obstruction. Thorax 1993;48:1156-9.

10. Pedersen U, Kristensen S, Illum P. Palliative resection with highfrequency cutting loop in malignant tracheobronchial diseases. J Bronchol 1994;1:23-5.

11. Sutedja G, van Kralingen K, Schramel FM, Postmus PE. Fibreoptic bronchoscopic electrosurgery under local anaesthesia for rapid palliation in patients with central airway malignancies: A preliminary report. Thorax 1994;49:1243-6.

12. Homasson JP, Roden S, Angebault M, Thuy MP, Phuong TN. [Treatment of bronchial tumors with high-frequency thermocoagulation. Preliminary studies]. Rev Pneumol Clin 1995;51:77-81.

13. Sutedja TG, van Boxem TJ, Schramel FM, van Felius C, Postmus PE. Endobronchial electrocautery is an excellent alternative for $\mathrm{Nd}$ :YAG laser to treat airway tumors. J Bronchol 1997;4:101-5. effects are delayed, and multiple treatments may be required. Treatment of large proximal lesions with brachytherapy may be associated with fistula formation and massive fatal hemoptysis and is, therefore, not recommended. The overall cost of a brachytherapy program is significant, although equipment is often shared by multiple specialists.

PDT can be effective in the treatment of malignant airway disease, but its effect is delayed, multiple procedures to remove necrotic debris are required and current photosensitizers are associated with significant prolonged skin photosensitivity.

\section{CONCLUSION}

The availability, relative simplicity, safety and modest cost of EE techniques (16) are bound to contribute to its expanding use. In our centres, EE (soft coagulation) and APC have replaced other modalities in the vast majority of cases. Issues such as training requirements and accreditation for performance of these procedures have yet to be resolved, but dedicated experienced teams are likely to improve success rates and reduce complications. Contact EE with soft coagulation is relatively easy to learn because the tactile feedback of the probe on the lesion and the proximal to distal application of EE leads to more precise delivery of energy and probable reduced risk of inadvertent airway perforation. While the principle indication for EE remains palliative debulking of endobronchial obstructions, undoubtedly, refinements in indications and techniques will continue to evolve.

14. Reichle G, Freitag H, Kullmann J, Prenzel R, Macha HN, Farin G. Argon plasma coagulation in bronchology: A new method alternative or complementary? J Bronchol 2000;7:109-17.

15. Coulter TD, Mehta AC. The heat is on: Impact of endobronchial electrosurgery on the need for Nd:YAG laser photoresection. Chest 2000;118:516-21.

16. van Boxem T, Muller M, Venmans B, Postmus P, Sutedja T. Nd-YAG laser vs bronchoscopic electrocautery for palliation of symptomatic airway obstruction: A cost-effectiveness study. Chest 1999;116:1108-12.

17. Morice RC, Ece T, Ece F, Keus L. Endobronchial argon plasma coagulation for treatment of hemoptysis and neoplastic airway obstruction. Chest 2001;119:781-7.

18. Okada S, Yamauchi H, Ishimori S, Satoh S, Sugawara H, Tanaba Y. Endoscopic surgery with a flexible bronchoscope and argon plasma coagulation for tracheobronchial tumors. J Thorac Cardiovasc Surg 2001;121:180-2.

19. van Boxem TJ, Venmans BJ, Schramel FM, et al. Radiographically occult lung cancer treated with fibreoptic bronchoscopic electrocautery: A pilot study of a simple and inexpensive technique. Eur Respir J 1998;11:169-72.

20. van Boxem TJ, Venmans BJ, van Mourik JC, Postmus PE, Sutedja TG. Bronchoscopic treatment of intraluminal typical carcinoid: A pilot study. J Thorac Cardiovasc Surg 1998;116:402-6.

21. Colt HC. Bronchoscopic resection of wallstent-associated granulation tissue using argon plasma coagulation. J Bronchol 19985:209-12.

22. Tremblay A, Coulter TD, Mehta AC. Modification of a mucosalsparing technique utilizing electrocautery and balloon dilatation in the endoscopic management of web-like benign airway stenosis. Am J Respir Crit Care Med 2001;163:A958. (Abst)

23. Bergler W, Honig M, Gotte K, Petroianu G, Hormann K. Treatment of recurrent respiratory papillomatosis with argon plasma coagulation. J Laryngol Otol 1997;111:381-4.

24. Brodsky JB. Anesthetic considerations for bronchoscopic procedures in patients with central-airway obstruction. J Bronchol 2001;8:36-43.

25. Sagawa M, Sato M, Takahashi H, Minowa M, Saito Y, Fujimura S. Electrosurgery with a fiberoptic bronchoscope and a snare for endotracheal/endobronchial tumors. J Thorac Cardiovasc Surg 1998;116:177-9. 


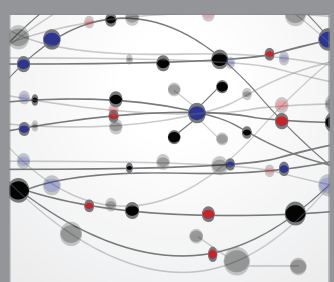

The Scientific World Journal
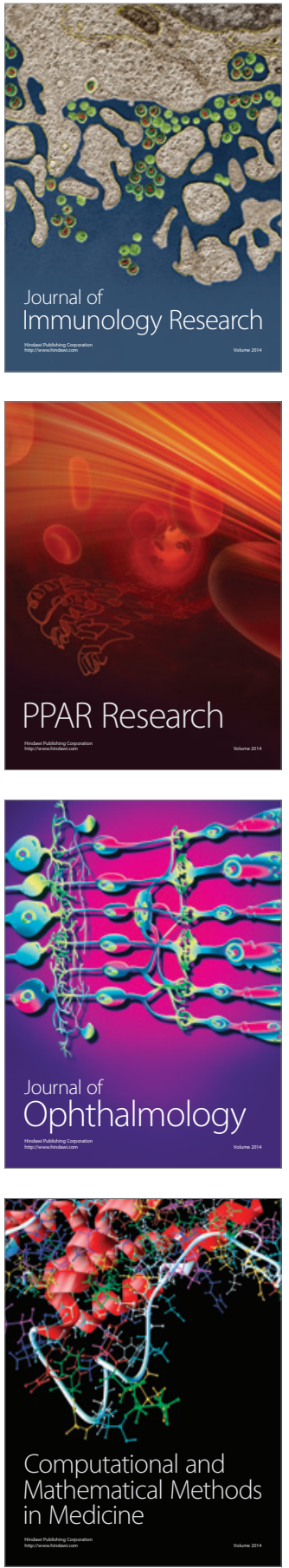

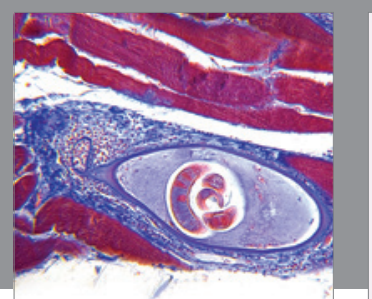

Gastroenterology Research and Practice

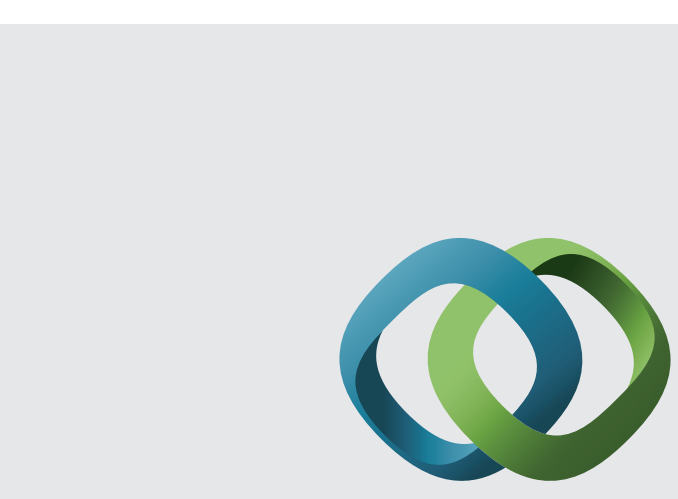

\section{Hindawi}

Submit your manuscripts at

http://www.hindawi.com
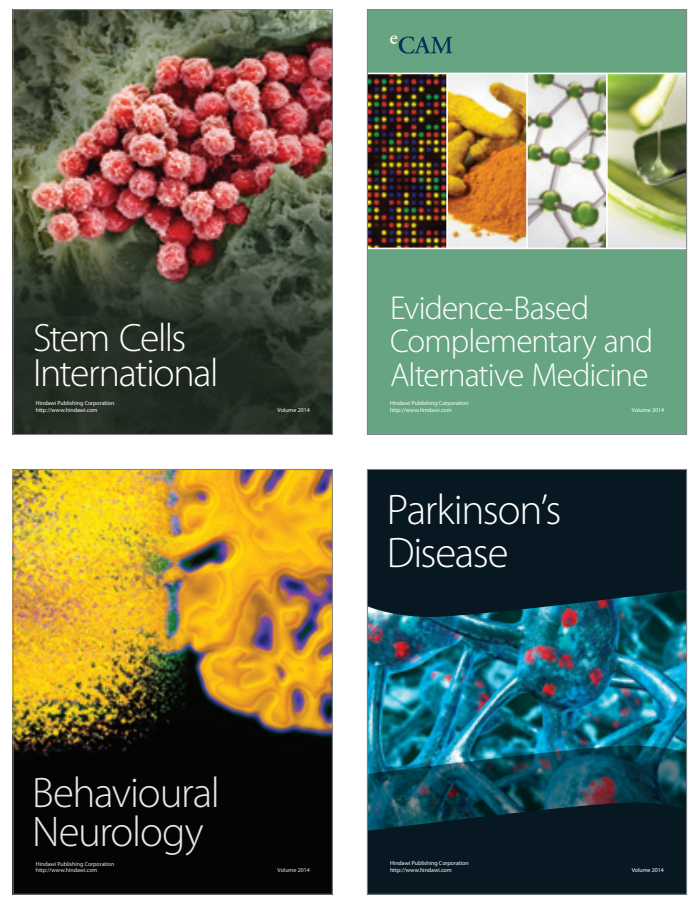
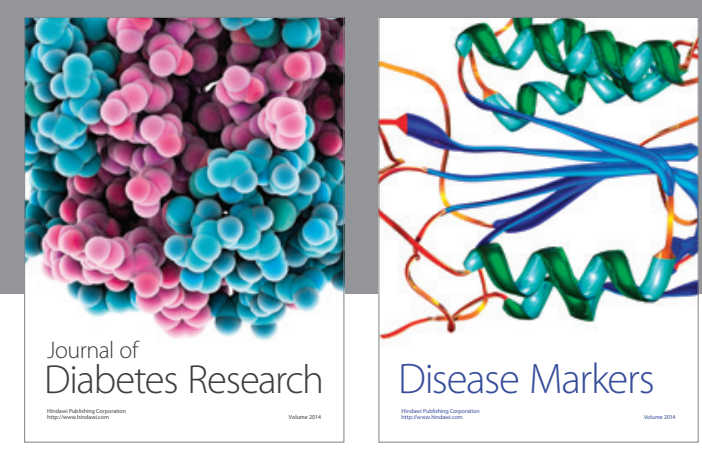

Disease Markers
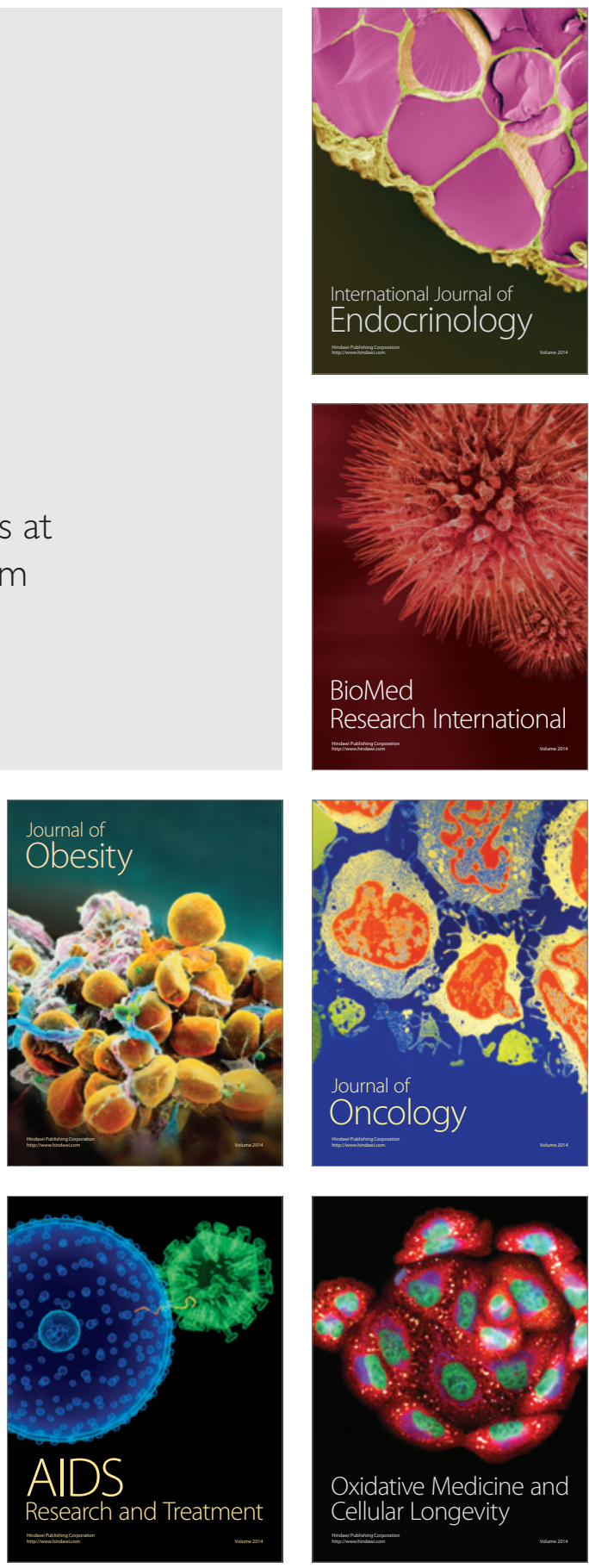